\title{
Compassion is Dissent
}

\section{The Institute for the Art and Practice of Dissent at Home*}

The contemporary neoliberal consensus means that compassion is dissent. Following the election of a right-wing Tory government committed to an economic policy of pernicious austerity in the May 2015 election in the UK, the Institute for the Art and Practice of Dissent at Home organized 'Compassion is Dissent: Manifesto Slam' which took place on 25 June 2015 at 7pm. We put out an open call on Critical Network, the Institute's website and social media. To get in, participants had to bring their own 3-minute Manifesto. They could deliver their Manifesto in any way they liked: slam it, sing it, dance it, read it, shout and scream it if they felt the need.

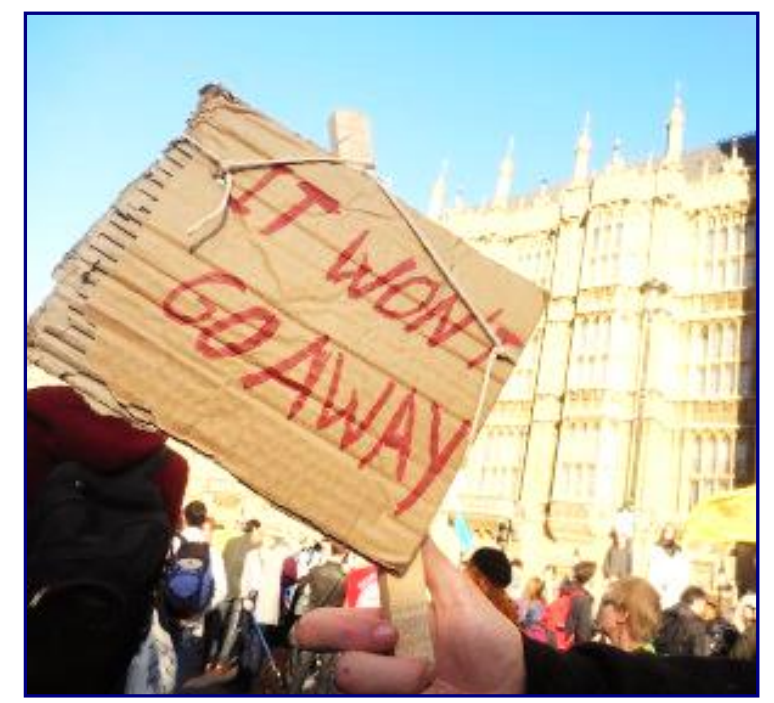

Figure 1. 'It Won't Go Away' placard in front of the Houses of Parliament, London, UK 2015. Photo courtesy of the Institute for the Art and Practice of Dissent at Home.

The open call:

The Institute knows a new political moment is upon us.

The prospect of another five years of the austerity assault machine has forced us to act. We want to activate ourselves and each other in the face of this Tory-ality, this No Future. We want to realise ourselves in action, to outwit, outgrow and outlast.

How can we spread the virus of compassion, how can we find new weapons of dissent? In our small, insignificant way, we are calling for the downfall of capitalism, starting with the crumbling of the neoliberal project and the simultaneous overthrowing of the current government.

Join us. You'll be suitably rewarded with drinks and the company of fellow revolutionaries. Let us know you're coming at theinstitute@twoaddthree.org

Solidarity.

The Manifesto Slam was inspired by UK based theatre-makers Chris Thorpe and Lucy Ellison's double bill of Confirmation and \#TORYCORE at the Unity Theatre in Liverpool on May 7 2015, the eve of the election, when social change for the better seemed vaguely plausible ... 
'The Compassion is Dissent: Manifesto Slam' stage and seating was prepared by the Institute on the eve before the slam. The stage spelled 'dissent', the seating 'compassion is a way'. This stage was the result of a recent Institute Makeover, with sincere thanks to Studio Polpo, a social enterprise architectural practice from Sheffield.
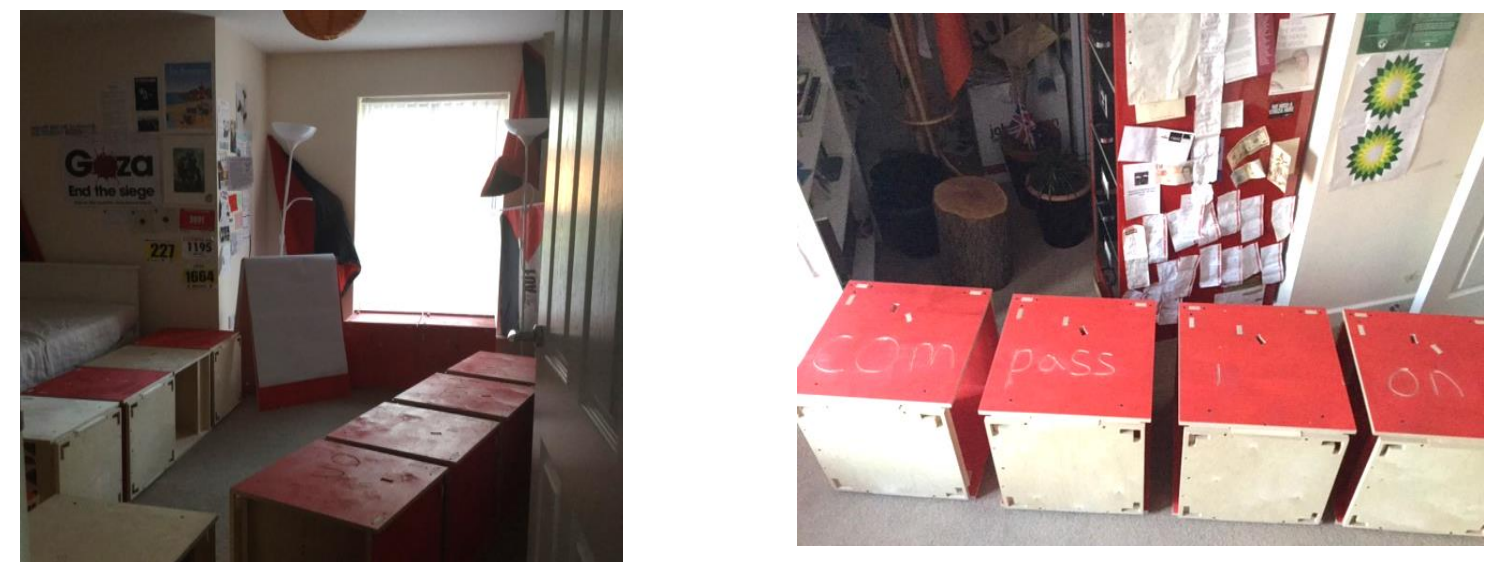

Figures 2 and 3. Setting for The Compassion is Dissent: Manifesto Slam, Liverpool, UK 2015. Photo courtesy of the Institute for the Art and Practice of Dissent at Home.

Slammers in feminist alphabetical order were Cathy Butterworth and Mark Greenwood, Gary Anderson, Jennifer Verson, Lena Šimić, Lorena Rivero de Beer, Mark Loudon, Michael Pierce, Paul Matosic (visual arts contribution), Tim Jeeves and Zoe Zontou (in absentia, delivered by Sid Anderson).

Time-keeper and compère was Sid Anderson. Sid also gave out prizes: six copies of the Communist Manifesto by Marx and Engels and one copy of 100 Artists' Manifestos: From the Futurists to the Stuckists (all purchased from the News from Nowhere radical bookstore in Liverpool, UK).

Distractors were babies Isaac and James.

Documentation was provided by Mark Loudon, who kindly photographed the event, and Gary Anderson, who audiorecorded it.

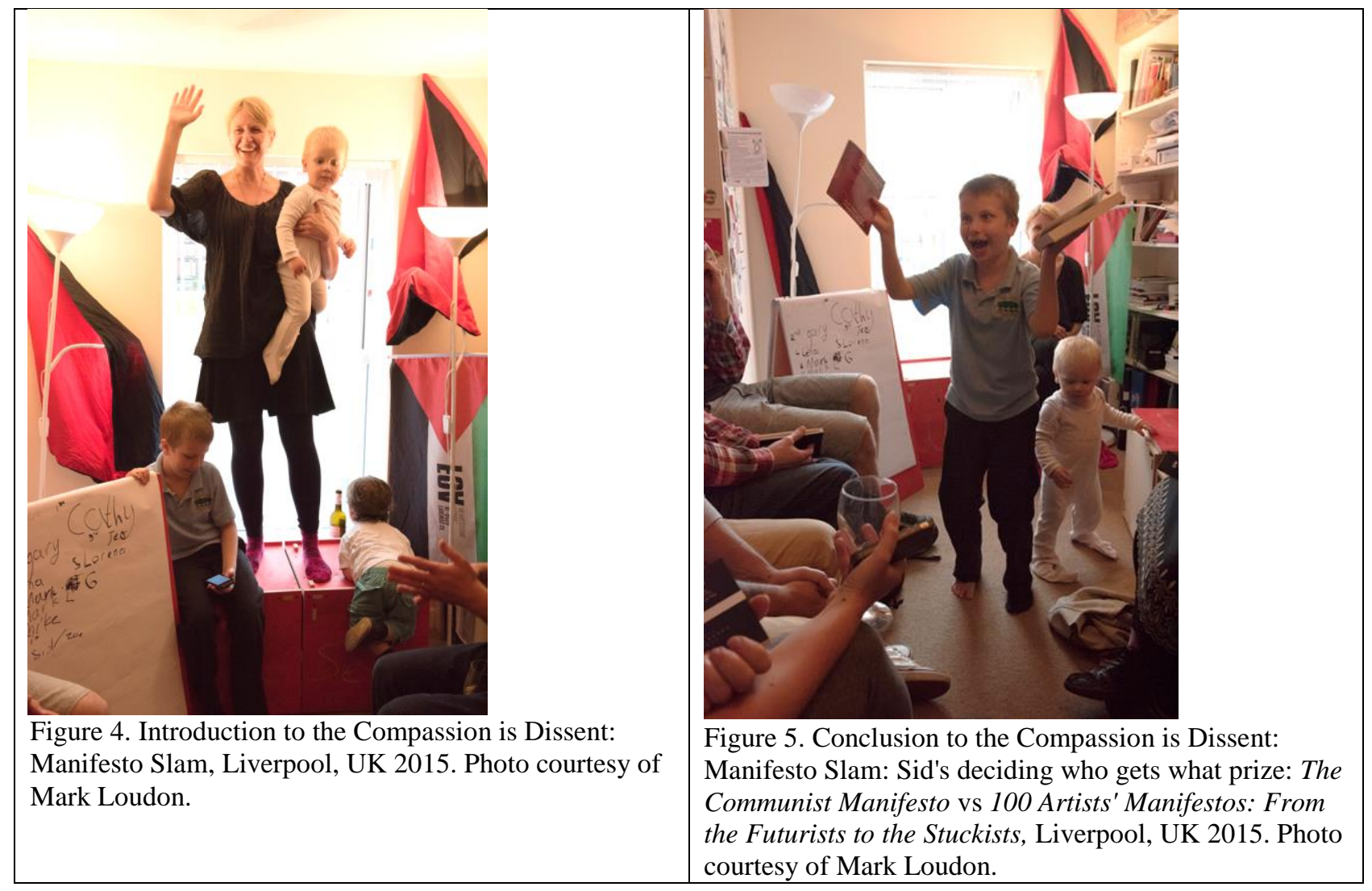


Here are the three slams by Gary Anderson, Jennifer Verson and Lena Šimić.

Gary Anderson: back of an envelope manifesto (after Manifesto for Maintenance Art! 1969 by Mierle Laderman Ukeles)

$\underline{\text { IDEAS }}$

A. The privatising instinct and the collectivising instinct.

The privatising instinct: separation/isolation, individuality, self-identifying as an ego, contemporary art par-excellence, to follow one's own part to privatising, doing your own thing, preventing others with your dynamic.

The collectivising instinct: integration, returning, relying, the perpetuation and maintenance of the species, common dependency, enabling others with your generosity and empathy.

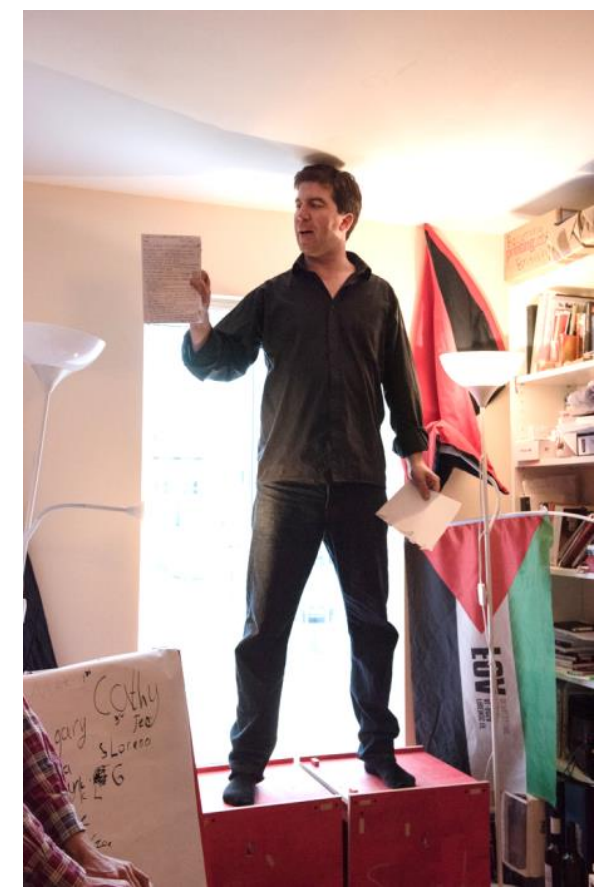

Figure 6. Gary Anderson at the Compassion is Dissent: Manifesto Slam, Liverpool, UK 2015. Photo courtesy of Mark Loudon.
B. Two basic systems: privatisation and Collectivisation.

The sourball of every privatising revolution: who's going to get paid enough to pick up the garbage on Bank Holiday Monday?

Privatisation: the systematic, cold disenfranchisement of everybody except the $1 \%$ !

Collectivisation: the consensual, warm, enfranchisement of the $99 \%$ ! Joyous, erotic, fulfilling social encounters.

C. Collectivisation: is a drag; it takes all the fucking time, literally; the mind boggles and chafes at the boredom of inner power struggles - no status, no rewards, no pay - collectivist $=$ no recognition or mis-recognition.

D. Politics: everything I say is politics is politics, everything I do is politics is politics 'politics is about who gets what, when and how'.

E. The demonstration of collectivisation.

'Manifesto Slam' would zero in on our utter opposition to the present undemocratically elected TORY privatisation machine and BRING IT DOWN. 


\section{Jennifer Verson: Compassion is Dead}

Compassion is dead

Compassion is colonial

Complexity is our only hope

Hope is colonial

Hope is not based on logic

Hope is based on faith

But we can diagram complexity

We can draw a picture of our lives

We can use arrows to indicate

the flow of wealth and resources

We can use equations

to explain

that the pavement we walk on

is not ours, it's not our inheritance

inheritance as in inherited wealth

as in the Queen is not the only one

who has a right to the inherited wealth

We can use a formula

to explain

that this park

this pavement

this job centre

belongs

to the children of Harare

that this park

this pavement

this job centre

belongs to the children of Lahore

that this park

this pavement

this job centre

belongs

to the children of Addis Ababa

it's not mine.

I don't belong here

my inheritance is scattered on a

sea shell strewn beach

in the Gulf of Mexico

where Ponce de Leon searched for a

fountain of youth

and Jose Gaspar built a prison

to hold his captives

My inheritance is a heart

that yearns for justice

We can diagram justice

We can map the relationship of the brothers and sisters

in Libya, Lampedusa and Calais

They remember this land

They remember their brothers and sisters and grandparent

giving their lives for king and country

They learned the words to God Save the King in missionary

schools in Rhodesia

They survived the middle passage

They fought Nazi armies, Fascist armies,

Imperial armies, with bayonets and machine guns so that

history could move forward in one direction

from genocide and apartheid

and a hatred of the other so systematically manufactured

as to logically frame the placement of humans beings on cattle cars.

We bought and sold

7 generations of Africans

We benefited from

12 million slaves

3.25 million on British ships

sailing across the Atlantic

We were on the side of

victory in 2 world wars

We buried 30000

members of the King's African Rifles

The men, women and children

camping on the beaches of Calais

do not need our compassion

They are just returning for

their inheritance

it is the Queen that should think

about sharing more fairly

with all of the children

of the Empire.

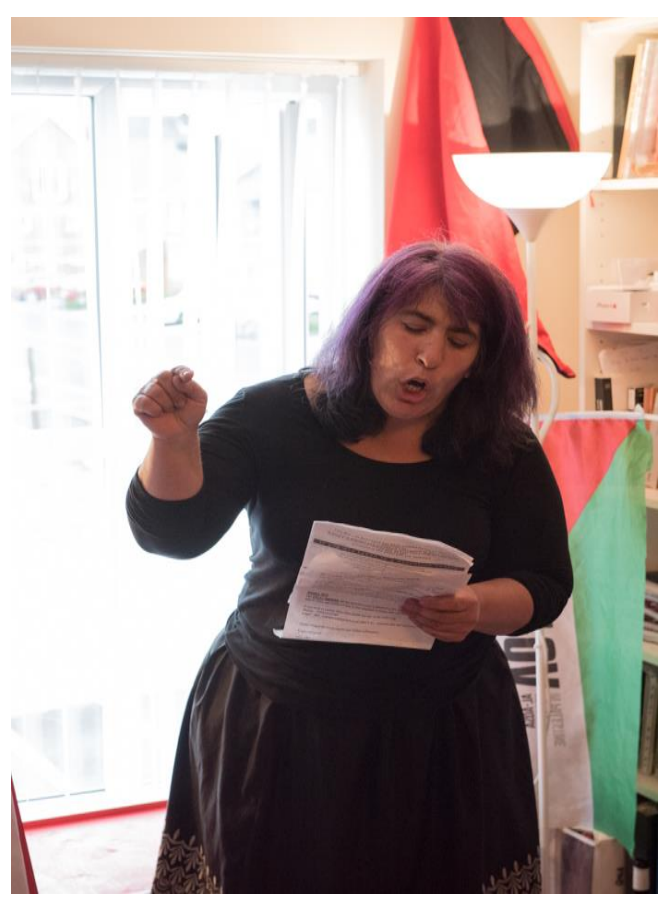

Figure 7. Jennifer Verson at the Compassion is Dissent: Manifesto Slam, Liverpool, UK 2015. Photo courtesy of Mark Loudon. 


\section{Lena Šimić: Today June 252015 at 18:10}

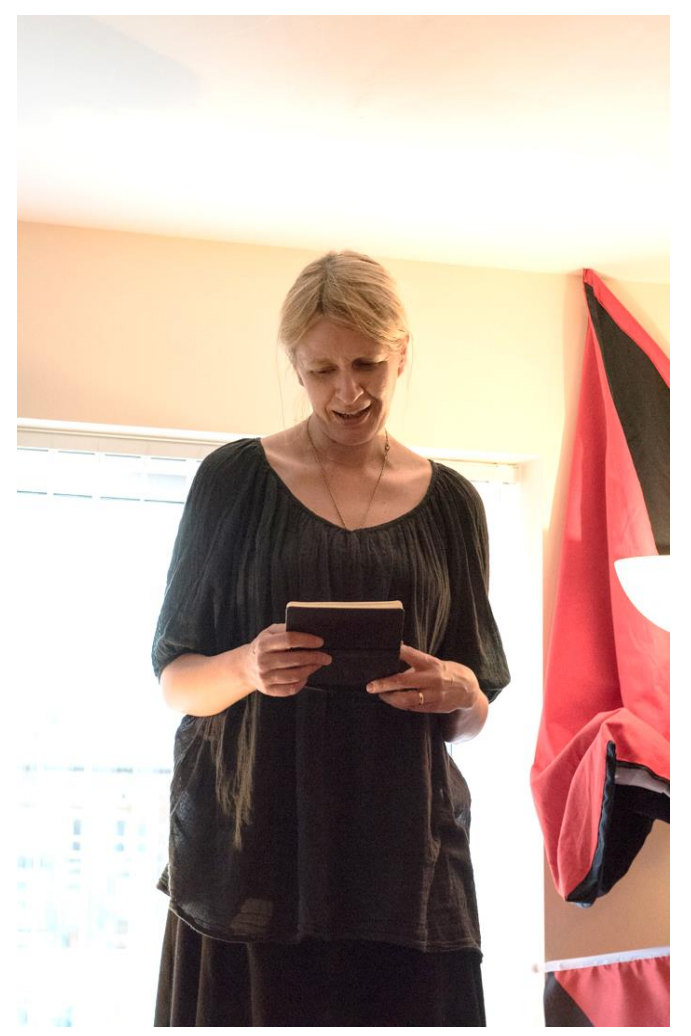

Figure 8. Lena Šimić at the Compassion is

Dissent: Manifesto Slam, Liverpool, UK 2015.

Photo courtesy of Mark Loudon.

Today June 252015 at 18:10 I fail again. The process of speaking, of having to speak, humbles me. These are not my words. There's this worry about the pernicious substitution of intimacy and warmth for justice, as Richard Sennett would say. Again, I am stealing here. Today words fail me. Today is too much. The summer of 2015 is upon us. Abandon hope (summer is coming!). What are our weapons of dissent? Banner poetics, a friend said. Today I will give you slogans, mostly those which I haven't invented. Today I am a producer. Today I don't invent the new. Today I am all reflection and no action. A paradox. What does it mean to begin, to initiate, to start? This is a philosophy of life, of natality, of action as Hannah Arendt would have it. Hannah Arendt, self-proclaimed political thinker, not a philosopher. Philosophy is set on contemplating death. 1. What's to be done? 2. Capitalism is crisis. 3. There is no need to fear or hope, only to look for new weapons.

A break. I'm cooking rice. My mind is steaming and empty.

IT IS A NEOLIBERAL CONSPIRACY TO DENY US OUR HUMAN RIGHT FOR A FUTURE LIFE THE CAPITALISTS ARE STEALING OUR MONEY AND OUR FUTURE

My friend Zoë Svendsen writes in headlines.

Today I am reliant on you. Today I will get through. Today I am taking on your instructions on how to live my life. I'm writing this manifesto. I'm cooking rice. One action interrupts the other. These days are given over ... These months I step aside ... I work in the background. I wonder what it is that makes one start something new, an action, an initiation. How does it begin? And today Mxiolisi Norman, my student, says: 'The process of speaking, of having to speak, humbles me.' 


\section{What's to be done - next? Take to the streets ... of our neighbouring town, St Helens!}

Developing anti-austerity, pro-people power tactics we write new manifestos for St Helens by invitation from the Live Art Development Agency and Heart of Glass, a St Helens based community arts project. Equipped with a bench we launch Manifestoval - a festival of manifestos - as part of the Through the Looking Glass Art Festival in the town (November 20-21 2015). Our research objective is to create a working methodology for the production and dissemination of dissent. To do this, as we did at home in June, we try our best to disturb the over-polite boundaries between the private and the public through the unlikely combination of live art making and family making. After some research it turns out that one of the most pressing issues in St Helens is the removal of benches from the privately owned Hardshaw Shopping Centre smack bang in the middle of the town centre. Old age pensioners, Mums and shoppers have nowhere warm to gather and rest. The local paper is full of protest and dissent about the removal of benches. We source a local, used garden bench from Gumtree for $£ 25$ and decorate the bench with stuff bought from the family run DIY store across the road from Heart of Glass. Let's take the to the streets with the bench. Let's invade the Hardshaw Shopping Centre and invite people to sit down and co-create a manifesto for St Helens.

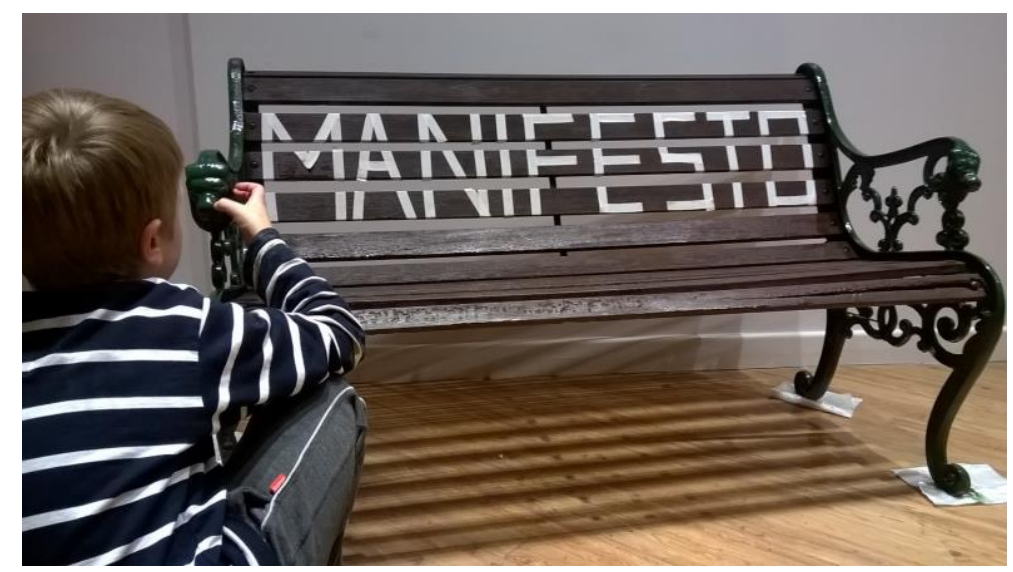

Figure 9. Sid applies the finishing touches to the Manifesto Bench, St Helens, UK 2015. Photo courtesy of the Institute for the Art and Practice of Dissent at Home

We spend the Saturday morning of November 212015 disturbing the Hardshaw Shopping Centre security guards. We brought the bench back in. Older ladies gather immediately, gleeful with mischief. We buy them cups of tea and chat about the removal of the benches from this privately owned space. We converse. We listen to their complaints. We provide a space for compassion and dissent. Sat on the bench with people compassion and dissent feel like such a natural couple. Eventually we are moved out of the shopping centre onto the streets of St Helens. We drag the bench around the Church Square again and again. People gather and talk to us. They know what we are doing. They know this is a cheeky protest. They want some of it. They want to talk. They want to dissent. We talk to the youngsters who want a skateboard lane in the square and the older folk who want their town centre back.

Our performance contribution ends up being called A Manifesto for St Helens by, for and of the People of St Helens and was delivered at $3 \mathrm{pm}$ that Saturday afternoon. A collection of thoughts from people who sat on the manifesto bench on Saturday November 212015 - transcribed and delivered on the day by the Institute. 
where to rest

where to rest

where to rest

when shopping

disgusting

fainting

nowhere to sit down

when meeting mum

a gathering place for the old

old people from homes

no benches

one seat

two seats

two seats

she wasn't allowed to feed the baby

bottles \& jars

customers dropped off

there used to be slabs with flowers

it's their money

it's private property

where's all the benches?

it's a hazard, they said

new manager

it's private property

so not here

can't talk at the library

just want to talk

old people haven't got much left

they just want to talk

old people sorting out their shopping on benches

open tj hughes

too many pound shops and charity shops

we need decent clothes shops

oh, surprised to see the bench here

they have them in warrington shopping centre

bus pass

injury to the back

two perfectly good cafes, they said

12 o'clock for a cup of tea?

reshuffle the st helens council

church square sold off

what do we own?

you are now making them work for their money they are finally worth it

i'd like to talk to him, a scouser we have loads of pound shops that's the third one that's opened and too many bakeries

that's the sixth make everything legal

better stores

less immigrants

no not you

it's world war three, innit?

no not you

a variety of shops

do you know how to spell that

less chavs

more clothes shops

skatepaths

we've been asking for skatepaths for two years

frank, the bench expert

facebook group, people of st helens

it will be there, your bench

there is just as much chance being killed right here in the road

i'm going on a coastal path

we don't need any more gyms or maccies

football team's struggling

just having a mooch

with a sense of community

wall - lost of a lot of character

historic buildings, got too quickly on the

redevelopment

late 60 s early $70 \mathrm{~s}$

replaced historic buildings

just look at, just look at

characterless, concrete monstrosities

rebuild the town centre

get rid of characterless, concrete monstrosities

new link road

outer centre ok

inner centre falling apart

heart of town centre

has been

pulled out

charity shops, betting officers

brighthouse - rip off shops

where's the money gonna come from?

guy, closing down fatface

has a 6 month lease -

here today gone tomorrow

not enough real engagement with

local population

long term project not sponsored by vested interests

we need st helens community trust

a group of people who represent

not vested interests

but a long term viable future

for this town 


\section{The gap that is left ...}

Precarity (the feeling that we are at the very edge of losing everything) is the basis of the current vile regime, the neoliberal order. To get us here it has taken the deliberate, conscious and strategic repositioning of the means of production as far away as possible from ordinary people. Agency, these days, seems almost inevitably to belong to those with the means necessary to further entrench us in sped-up consumer capitalism and its concomitant conditions. But, from working with people face-to-face at home and in the streets, listening and thinking things through with others, we get the distinct sense that the current vile regime is itself precarious. Neoliberalism is fragile. When agency is taken away from us to such an obvious extent it somehow, paradoxically, jolts us into an understanding of the gap that is left and the feeling begins to well inside that we simply must do something about it. As a family of two adults and four children we take sustenance from these insignificant actions we do at home and on the streets. Every time we do something like this people just seem to come out of the woodwork to join us. Dissent is everywhere. Compassion is everywhere.

\section{Notes on contributor}

The Institute for the Art and Practice of Dissent at Home are a family of two adults Gary Anderson and Lena Šimić and their four children Neal, Gabriel, Sid and James. They have been running an art activist initiative in their family home in Liverpool (UK) since 2007. They are funded by $10 \%$ of all income that comes through the family.

\section{References}

Arendt, Hannah. 1958. The Human Condition. University of Chicago Press.

Sennett, Richard. 1977. The Fall of Public Man, New York: Knopf.

Ukeles, Mierle Laderman. 1971. 'Manifesto For Maintenance Art 1969! Proposal for an exhibition "Care”". Originally published in Jack Burnham. 'Problems of Criticism.' Artforum 41 (January). Reprinted in Lucy Lippard. 1979. Six Years: The Dematerialization of the Art Object. New York: New York University Press, 1979. p. 220-221. 